The International Journal of

Sustainability Policy

and Practice

Stakeholder Collaboration Models for

Public Transport Procurement of

Electric Bus Systems 


\section{EDITOR}

David Humphreys, The Open University, UK

\section{HEAD OF JOURNAL PRODUCTION}

McCall Macomber, Common Ground Research Networks, USA

\section{EDITORIAL ASSISTANT}

Helen Repp, Common Ground Research Networks, USA

\section{ADVISORY BOARD}

The On Sustainability Research Network recognizes the contribution of many in the evolution of the Research Network. The principal role of the Advisory Board has been, and is, to drive the overall intellectual direction of the Research Network. A full list of members can be found at https://onsustainability.com/about/advisory-board.

\section{PEER REVIEW}

Articles published in The International Journal of Sustainability Policy and Practice are peer reviewed using a two-way anonymous peer review model. Reviewers are active participants of the On Sustainability Research Network or a thematically related Research Network. The publisher, editors, reviewers, and authors all agree upon the following standards of expected ethical behavior, which are based on the Committee on Publication Ethics (COPE) Codes of Conduct and Best Practice Guidelines. More information can be found at: https://onsustainability.com/journals/model.

\section{ARTICLE SUBMISSION}

The International Journal of Sustainability Policy and Practice publishes biannually (June, December).

To find out more about the submission process, please visit https://onsustainability.com/journals/call-for-papers.

\section{THE INTERNATIONAL JOURNAL OF}

\section{SUSTAINABILITY POLICY AND PRACTICE}

https://onsustainability.com

ISSN: 2325-1166 (Print)

ISSN: 2325-1182 (Online)

https://doi.org/10.18848/2325-1166/CGP (Journal)

First published by Common Ground Research Networks in 2019 University of Illinois Research Park

2001 South First Street, Suite 202

Champaign, IL 61820 USA

$\mathrm{Ph}:+1-217-328-0405$

https://cgnetworks.org

The International Journal of Sustainability Policy and Practice is a peer-reviewed, scholarly journal.

\section{COPYRIGHT}

(C) 2019 (individual papers), the author(s)

(C) 2019 (selection and editorial matter),

Common Ground Research Networks

All rights reserved. Apart from fair dealing for the purposes of study, research, criticism, or review, as permitted under the applicable copyright legislation, no part of this work may be reproduced by any process without written permission from the publisher. For permissions and other inquiries, please contact support@egnetworks.org.

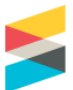

\section{Crossref}

Common Ground Research Networks, a member of Crossref

\section{ABSTRACTING AND INDEXING}

For a full list of databases in which this journal is indexed, please visit https://onsustainability.com/journals/collection.

\section{RESEARCH NETWORK MEMBERSHIP}

Authors in The International Journal of Sustainability Policy and Practice are members of the On Sustainability Research Network or a thematically related Research Network. Members receive access to journal content. To find out more, visit https://onsustainability.com/about/become-a-member.

\section{SUBSCRIPTIONS}

The International Journal of Sustainability Policy and Practice is available in electronic and print formats. Subscribe to gain access to content from the current year and the entire backlist. Contact us at support@cgnetworks.org.

\section{ORDERING}

Single articles and issues are available from the journal bookstore at https://cgscholar.com/bookstore.

\section{HYBRID OPEN ACCESS}

The International Journal of Sustainability Policy and Practice is Hybrid Open Access, meaning authors can choose to make their articles open access. This allows their work to reach an even wider audience, broadening the dissemination of their research. To find out more, please visit https://onsustainability.com/journals/hybrid-open-access.

\section{DISCLAIMER}

The authors, editors, and publisher will not accept any legal responsibility for any errors or omissions that may have been made in this publication. The publisher makes no warranty, express or implied, with respect to the material contained herein. 


\title{
Stakeholder Collaboration Models for Public Transport Procurement of Electric Bus Systems
}

\author{
Sven Borén, ${ }^{1}$ Blekinge Institute of Technology, Sweden \\ Anders Grauers, Chalmers University of Technology, Sweden
}

\begin{abstract}
Earlier studies have mainly focused on technology, economy, and advantages of electric buses, and they have largely shown that electric buses could be one of the solutions for sustainable public transport. Despite this, the present procurement process for public transport in Sweden is not suitable for including support systems for electric buses. This study was aimed to find a stakeholder collaboration model that would allow electric bus systems to be more effectively included in the procurement process for public transport. The results were achieved by several multi-stakeholder collaboration seminars and meetings that included representatives from regional public transport authorities, bus operators, bus manufacturers, energy companies, municipalities, and experts involved in bus transport. The study primarily developed two stakeholder collaboration models, suggesting that charging infrastructure should be designed separately from the common procurement process. In these models, energy companies, electric grid owners, charging infrastructure operators, regional public transport authorities, and municipalities need to collaborate. The first model is designed for a system that includes chargers at certain locations along a route and/or stakeholders with a low level of experience of electric bus systems, while the second is designed for a system that includes bus charging at the depot and/or stakeholders with a high level of experience of electric bus systems.
\end{abstract}

Keywords: Electric Bus, Stakeholder, Collaboration, Bus Procurement, Strategic Sustainable Development, Charging

\section{Introduction}

$\mathrm{E}$ lectric-powered buses contribute to the sustainable development of public transport as they have very low emissions in the use phase and lower noise levels compared to buses powered by combustion engines (Johansson et al. 2013; Ecotraffic 2015; Borén, Nurhadi, and Ny 2016). In general, electric vehicles (EVs) should be powered by electricity from new renewable and sustainably managed sources (Faria et al. 2012; Hawkins et al. 2012; Nurhadi, Borén, and Ny 2014). More precisely, Faria et al. (2012) used a Well-to-Wheel approach in the life cycle assessment and concluded for example that "for the present EU mix, the emissions reduction impact is substantial, and will be reduced even more in the future due to the increasing use of renewable energies in the energy mix." Other life-cycle assessment studies have also found that life-cycle environmental impacts are significantly lower from electric buses than from buses with internal combustion engines if they are powered by renewable electricity (Nordelöf et al. 2014; Nordelöf, Romare, and Tivander 2017; Edwards et al. 2014; Hallberg et al. 2013). A sustainable future is defined by sustainability principles (SPs) (Broman and Robèrt 2017). As all other electric vehicles, electric buses have the possibility to play an important role in the fast transition towards sustainability if recycling of batteries is increased, recycling is developed for all substances that are violating SPs, and when mining and transport are powered by fossil-free energy (Borén and Ny 2016b). An increase of electric buses would therefore contribute to the fulfillment of societal transport related goals. This includes the Swedish goals to get a fossil-fuelindependent vehicle fleet by 2030 , greenhouse gas neutral society by 2045 , and lower noise levels in cities, as well as the global Paris Agreement (United Nations 2015) to keep the global warming well below two degrees in line with the UN Sustainable Development Goals. In 2017, there were $370,000(3.6 \%)$ electric powered buses (including trolleys, plug-in hybrids, and battery buses) in operation globally (UITP 2017). This is expected to grow to 15 to 30 percent by 2030 globally (Cazzola 2018), and to above 50 percent in the EU by 2030 (UITP 2017). There is

\footnotetext{
${ }^{1}$ Corresponding Author: Sven Borén, Department of Strategic Sustainable Development, Blekinge Institute of Technology, 37179 Karlskrona, Sweden. email: sven.boren@bth.se
}

The International Journal of Sustainability Policy and Practice Volume 15, Issue 1, 2019, https://onsustainability.com (C) Common Ground Research Networks, Sven Borén, Anders Grauers, All Rights Reserved. Permissions: support@cgnetworks.org ISSN: 2325-1166 (Print), ISSN: 2325-1182 (Online)

https://doi.org/10.18848/2325-1166/CGP/v15i01/19-29 (Article) 
a common believe in, and existing and potential advantages and disadvantages for electric buses. As mentioned above, there are, though, some concerns regarding initial investments (e.g., price of buses and infrastructure), how to integrate charging with the city environment, and knowledge/experience among stakeholders (Wei et al. 2018; Ekström and Regula 2016; Xylia et al. 2017).

Transport planning in Sweden is done at the national level by the Swedish Transport Administration and at the regional level by regional Public Transport Authorities (PTAs) through regional Traffic Supply Program (TSP). To follow these, it is common that respective PTAs procure bus traffic/services from an operator for a period of ten years. This operator then, in turn, acquires buses, staff, and supporting infrastructure like workshops and bus depots. This process is quite complicated as several different actors must deal with different parts of the problem in a coordinated way. The procurement process (Figure 1) has been refined throughout many years to optimize procurement of bus traffic that traditionally are powered by combustion engines. There are some steps in the process about stakeholder collaboration, but these are insufficient for being able to agree upon how to redesign bus systems to fit a new technology (Borén 2015).

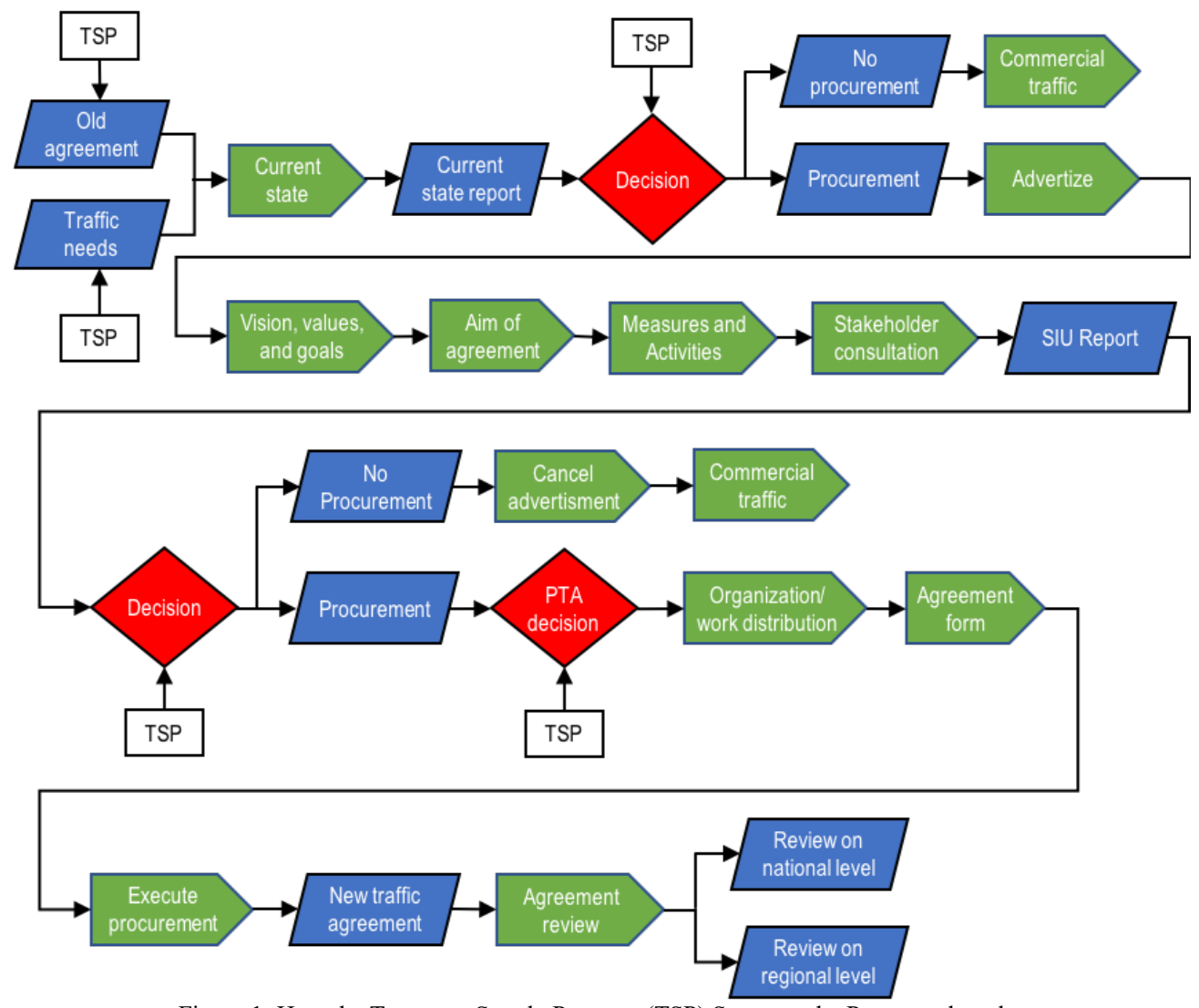

Figure 1: How the Transport Supply Program (TSP) Supports the Process when the Key Stakeholders Make a New Public Transport Traffic Agreement Source: Translated from Svensk Kollektivtrafik AB et al. 2013

When new systems are introduced to a market, the knowledge level among stakeholders is, in general, low, and there is a need for stakeholders to eventually agree upon a smooth introduction that fulfills requirements from both users and suppliers. For the implementation of electric bus systems, lack of knowledge and experience, ownership of buses and infrastructure, and business models have, among others, been indicated as barriers (Ekström and Regula 2016). 
Moreover, the need for further collaboration among stakeholders in the Swedish public transport sector has been highlighted recently, especially regarding routines and processes for collaboration (Paulsson et al. 2018). There are several cost optimization models being launched lately to enhance the introduction of electric buses (Wei et al. 2018; Xylia et al. 2017), but without enhancing stakeholder collaboration for increased knowledge about electric bus systems. Moreover, Green Public Procurement can be used for public procurement of systems that contributes sustainable development, but that concept rather addresses gaps in knowledge by setting procurements requirements (Aldenius and Khan 2017), instead of enhancing increased knowledge. To address the needs for coordination between stakeholders of public bus transport in Sweden, the authors of this study in 2015 asked bus public transport stakeholders to join a project about decision support for electric buses. Public Transport Authorities (PTAs), municipalities, energy companies, bus operators, bus manufacturers, and public transport related agencies joined the project. The project included partners that are active in existing electric public bus transport in the Swedish cities Gothenburg, Karlstad, Västerås, Umeå, and Ängelholm. Different electric buses from BYD, Hybricon, Optare, Solaris, and Volvo were used.

\section{Aim and Scope}

This study is one part of the larger research project about decision support for electric buses (Borén and Ny 2016a) described above. This study aimed, through stakeholder collaboration, to investigate how to include electric bus systems in the current procurement process. The study is based on results from investigations about costs and noise from electric buses, as well as from testing and development of a model that guides the design of electric bus ecosystem with a focus on charging.

\section{Methods}

Apart from initial studies through reviews of academic and topic-specific literature, the study was designed to retrieve information through stakeholders via project-internal workshops, but also via interviews with experts in the field, and feedback from stakeholders. The first workshop was designed to focus on stakeholder collaboration that would answer questions concerning how electric buses and supporting infrastructure could be included in the procurement process for bus traffic. Answers to these questions where partly informing the results of this study, but also informing further discussions within the topic. That workshop took place on April 12th, 2016, in Gothenburg with nineteen representatives from Blekinge Institute of Technology, Chalmers University, Göteborg Energi, Electrodriving, Region Blekinge, Region Jönköpings län, Nobina, Karlstadsbuss, Karlskrona Kommun, Orust kommun, Skånetrafiken, Svealandstrafiken AB, Svensk Kollektivtrafik, and Volvo Buses. The results from that workshop were then scrutinized by the authors of this article, with some help via interviews and discussions with stakeholder experts. Several issues about introducing electric buses in existing public transport were then identified and discussed among stakeholders at the second workshop in order to arrive at a common understanding of how to handle electric buses in the procurement process. For this workshop, the authors of this study sent a draft version of the stakeholder collaboration model to the stakeholders in the project to prepare themselves for discussions in the workshop, and also to get feedback from those who could not attend. That workshop took place March 15th, 2017, in Stockholm with seventeen representatives from Blekinge Institute of Technology, Chalmers University, Electrodriving, Region Blekinge, Region Jönköpings län, Nobina, Karlstadsbuss, Orust kommun, Skånetrafiken, Stockholms Lokaltrafik, Svealandstrafiken AB, Svensk Kollektivtrafik, Vattenfall AB, and Volvo Buses. These results were then scrutinized by the authors of this article and discussed with stakeholder experts, presented at the "On Sustainability" conference in January 2018 in Cairns, Australia, and then further developed to what is described in this article. 


\section{Results}

\section{Early Findings}

In line with earlier studies (Nurhadi, Borén, and Ny 2014; Ecotraffic 2015), the first workshop in Gothenburg pointed out that the chargers in an electric bus system have an important effect on the total cost of ownership, as well as on the size of the expensive battery in the bus. The workshop also agreed that the electric bus concept is currently new to many bus operators, and probably only the experienced would answer a tender including electric buses. The introduction of biogas-powered buses in Sweden a decade ago can be a parallel that can provide insights into the challenges presented by new fueling systems.

The workshop participants agreed that it is preferable for the electric bus system to be designed before the procurement phase, and it would be preferable that several stakeholders are involved in the design of the electric bus system. This design phase could fit into the step "Stakeholder consultation" before the SIU (Consultation before Procurement) report step in the procurement process (Figure 1). The system design phase would then include dialogues about standards, bus ecosystem design, charging infrastructure, and then procurement and construction of charging infrastructure. In addition to respective regional PTAs and interested bus traffic/service operators, it is important that the following stakeholders are involved in that design phase:

- City planners, as the location of fast charging stations might affect an existing or an upcoming local plan, or might not be possible to install at some locations without timeconsuming investigations and revision of local plans.

- Electricity grid owners, to account for the electricity use from chargers and estimate possible actions and costs to strengthen or extend the distribution grid.

- Electric bus charger operators, to add knowledge about charging systems and to coordinate with any other vehicle charging systems nearby.

- Bus manufacturers, to add knowledge about electric bus solutions and the development within electrified drivelines for buses and upcoming offers.

The workshop participants also agreed that there might be different types of models that could complement the existing procurement process, also depending on other factors than the competence about or experience of electric bus systems among stakeholders. The process might also be different if the buses are charged on specific locations along the route (i.e., "opportunity charging" with $200-500 \mathrm{~kW}$ in less than ten minutes), or at the bus depot (i.e., "depot charging" with $30-100 \mathrm{~kW}$ for three to ten hours).

The workshop participants also agreed that the procurement process can be kept mainly as it is now, but a new process for procurement and/or supply of new infrastructure is needed. Secondly it was concluded that it is not clear who should own the electric buses and the charging infrastructure.

\section{Refinement of Results}

Based on the results from the first workshop in Gothenburg, the authors of this article had considered several ways to add to or complement the existing procurement model. During that process the authors found that due to the current development of batteries, it is likely that batteries and charging infrastructure will be depreciated within ten years, which is the same as the recommended length of a contract for bus operators. It also became clear for the authors during discussions with stakeholders and interviews with experts that it would be preferable that bus operators would continue to own the buses, and that charging operators should own the charging infrastructure and then subcontract services to operators. 
The authors conceptualized a model based on opportunity charging where municipalities played a bigger role than today regarding design and establishment of charging infrastructure and discussed it with selected stakeholders and experts within the study. It was apparent to the authors that a several bus operators with experience in electric bus systems would like to have more responsibility during the design phase and eventually follow the existing procurement process without a pre-design phase for charging infrastructure. As mentioned earlier, that could create delays in the commissioning of bus traffic if city planners and grids owners were required to conduct additional investigations into the suitability of the proposals. Then they might need to change plans and build infrastructure to fit in a station for opportunity charging. Therefore, such a procurement process may make opportunity charging infeasible, as it is expected to be much easier to acquire building permits and grid connections faster inside a depot only, rather than on multiple places in the city.

At the second workshop in Stockholm, the authors presented a model based on opportunity charging that included several development steps for stakeholder collaboration before the traffic procurement process. As mentioned earlier, the first step would include dialogues about the entire bus ecosystem, the second step the design of the charging infrastructure, and the third step the procurement and construction of the charging infrastructure. The fourth and fifth steps would be about procurement of bus traffic and operation and maintenance of the bus system, respectively. Because of different levels of responsibility and engagement, stakeholders should be involved to various extents. One stakeholder has to be responsible for leading each step and then hand over to next step's responsible stakeholder, and other stakeholders either have to be involved or can volunteer to participate in each step.

Participants at the workshop in Stockholm agreed that the steps in the presented model were, in general, acceptable, but responsibility for the design and construction of charging infrastructure raised some concern. Some stakeholders urged that a public funded authority (e.g., PTA or municipality) needs to lead these steps because of competitive reasons so no operators would have a favorable position in the bus traffic procurement step. Others believed that it would be more cost-efficient if charging operators or bus operators would lead these steps and also be responsible for constructing the charging infrastructure. The latter would, for competition reasons, require that the construction of charging infrastructure is included in the bus traffic procurement phase and also that stakeholders (especially PTAs and charging/bus operators) are experienced regarding electric bus systems. The workshop participants also agreed that even if the chargers are to be built by the bus operator who wins the contract, it would be preferable if possible places for opportunity charging were agreed upon in the first steps about bus ecosystem and charging infrastructure design, and then approved by city planners and electricity grid owners before the procurement step was started. Pre-approved building permits can then be used by the operator who wins the contract to build charging infrastructure. A similar solution can also be used for planning grid extensions or strengthening the existing grid before the procurement, in order to make costs and timing constraints known to all operators.

\section{Proposed Models for Stakeholder Collaboration}

In line with agreements and discussions in this study, a stakeholder collaboration model for procurement of electric bus systems with opportunity charging and/or stakeholders with a low level of experience of electric bus systems was suggested (Figure 2). This model could, because of competitive rules/regulations, hinder the charging operator to participate in the bus traffic procurement step. Anyone involved in planning and building the chargers would have an advantage over other operators, which would not be acceptable in a public procurement. This can become a problem if a bus traffic operator organization includes, or is affiliated with, a charging operator. Accordingly, PTAs should contract a charging operator instead of a bus operator for the construction of charging infrastructure. The model is therefore flexible regarding who should be responsible and lead the steps about charging infrastructure design and construction, but the first 
step about design of the ecosystem (e.g., routing, bus size, and type of drivetrain) needs to be led by PTAs.

\begin{tabular}{|c|c|c|c|c|c|}
\hline PT model phase & "Stakeholde & consultation" & "Procure & ment" & \\
\hline Stakeholder/Role & $\begin{array}{c}\text { Bus } \\
\text { ecosystem }\end{array}$ & $\begin{array}{c}\text { Charging infra. } \\
\text { design }\end{array}$ & $\begin{array}{l}\text { Charging infra. } \\
\text { construction }\end{array}$ & $\begin{array}{l}\text { Bus traffic } \\
\text { procurement }\end{array}$ & $\begin{array}{l}\text { Operation and } \\
\text { maintenance }\end{array}$ \\
\hline $\begin{array}{l}\text { Electricity } \\
\text { dealers }\end{array}$ & & & & I & I \\
\hline $\begin{array}{l}\text { Electricity grid } \\
\text { owners }\end{array}$ & V & 1 & I & 4 & $\mathrm{R}_{2}$ \\
\hline $\begin{array}{c}\text { Charging } \\
\text { manufacturers }\end{array}$ & V & 1 & I & & $\mathrm{R}_{2}$ \\
\hline $\begin{array}{l}\text { Charging } \\
\text { operators }\end{array}$ & I & $\mathrm{R} / \mathrm{l}$ & $\mathrm{R}_{2} / \mathrm{l}$ & $R_{3}$ & $\mathrm{R}_{2}$ \\
\hline $\begin{array}{l}\text { City planners/ } \\
\text { municipality }\end{array}$ & I & I & $\mathrm{I} / \mathrm{R}_{2}$ & I & V \\
\hline $\begin{array}{l}\text { Public transport } \\
\text { authority }\end{array}$ & $\mathrm{R}$ & I/R & $\mathrm{R}_{1}$ & $\mathrm{R}_{1}$ & I \\
\hline $\begin{array}{l}\text { Bus traffic } \\
\text { operators }\end{array}$ & I & I & I & $\mathrm{R}_{2}$ & $\mathrm{R}_{1}$ \\
\hline $\begin{array}{c}\text { Bus } \\
\text { manufacturers }\end{array}$ & 1 & I & V & I & $\mathrm{R}_{2}$ \\
\hline
\end{tabular}

$$
\text { R: Responsible I: Involved V: Volunteer } \boldsymbol{\uparrow} \text { : Contract }
$$

Figure 2: A stakeholder collaboration model tailored for opportunity charging and stakeholders with a low level of experiences regarding procurement of electric bus systems. The model includes stakeholders/roles and their leaderships/responsibilities (in sequence 1-3), which partners to establish contracts with, and also steps that fits into different parts of the procurement process model (Figure 1).

Source: Borén and Grauers 2018

The timeframe for each stakeholder collaboration step varies as there can be weeks or months between the first two steps, but there can be a delay of up to several years between design and construction of charging infrastructure due to processing of building permits and/or redesign of the electricity grid. Added to that, the construction step has to be procured by the regional PTA via a public procurement process. It could, though, still overlap with the bus traffic procurement step, but the charging infrastructure should be operational before commissioning of the bus traffic. The stakeholders should, therefore, be aware that the process of procuring bus traffic might take longer time when using this model but will, on the other hand, not risk redoing the process as it has been done properly.

The workshop participants in Stockholm agreed that there is a need for another model that deals with stakeholders that have enough experience and knowledge regarding electric bus systems to include construction of the charging infrastructure in the bus traffic procurement step. There were also discussions about whether bus operators should take full responsibility regarding designing the entire electric bus ecosystem. As mentioned earlier, there would still be a need for having discussions with affected stakeholders about the design of the bus ecosystem and, in particular, the charging infrastructure, to not delay commissioning of the bus traffic. Another issue that was not accounted for in the first model is when the electric buses are charged at the bus depot, as that includes less complicated investments by the bus operator and each bus has a charger at the depot. The scenario where bus operators take full responsibility for the design of the electric bus ecosystem still requires a discussion about the design of the bus ecosystem and charging infrastructure to agree where and how the buses should be charged. Added to that, bus 
operators might find out in the procurement bidding process that it would be preferable to offer electric buses powered by opportunity charging (and vice versa). It is therefore important that the model is flexible enough to include such variations, and that initial stakeholder collaboration steps (bus ecosystem and charging infrastructure design) identify suitable locations for, or at least necessary actions and investments for establishment of, opportunity charging and also of depots that allows charging of electric buses. It will then be up to bus operators to individually or jointly lead the step of initial charging infrastructure design. To account for issues mentioned above, which are not included in the first model, the authors propose an alternative model (Figure 3).

\begin{tabular}{|c|c|c|c|c|}
\hline PT model phase & \multicolumn{2}{|c|}{ "Stakeholder consultation" } & "Procurement" & \multirow[b]{2}{*}{$\begin{array}{l}\text { Operation and } \\
\text { maintenance }\end{array}$} \\
\hline Stakeholder/Role & $\begin{array}{c}\text { Bus } \\
\text { ecosystem }\end{array}$ & $\begin{array}{l}\text { Initial charging } \\
\text { infra. design }\end{array}$ & \rangle $\left.\begin{array}{c}\text { Bus traffic procurement }+ \\
\text { charging infra. construction }\end{array}\right\rangle$ & \\
\hline Electricity dealers & & & 1 & I \\
\hline $\begin{array}{l}\text { Electricity grid } \\
\text { owners }\end{array}$ & V & I & I & $\mathrm{R}_{2}$ \\
\hline $\begin{array}{c}\text { Charging } \\
\text { manufacturers }\end{array}$ & V & I & & $\mathrm{R}_{2}$ \\
\hline $\begin{array}{l}\text { Charging } \\
\text { operators }\end{array}$ & I & I & & $\mathrm{R}_{2}$ \\
\hline $\begin{array}{l}\text { City planners/ } \\
\text { municipalities }\end{array}$ & I & I & 1 & V \\
\hline $\begin{array}{l}\text { Public transport } \\
\text { authority }\end{array}$ & $\mathrm{R}$ & I & $\mathrm{R}_{1}$ & I \\
\hline $\begin{array}{l}\text { Bus traffic } \\
\text { operators }\end{array}$ & I & $\mathrm{R}$ & & $\mathrm{R}_{1}$ \\
\hline $\begin{array}{c}\text { Bus } \\
\text { manufacturers }\end{array}$ & I & V & I & $\mathrm{R}_{2}$ \\
\hline
\end{tabular}

R: Responsible I: Involved V: Volunteer $\mathbf{\uparrow}$ : Conctract

Figure 3: An alternative stakeholder collaboration model tailored for depot charging and/or stakeholders with a high level of experiences regarding procurement of electric bus systems including their chargers. The model includes stakeholders/roles and their leaderships/responsibilities (in sequence 1-2), which partners to establish contracts with, and also steps that fits into different parts of the procurement process model (Figure 1).

Source: Borén and Grauers 2018

As shown in Figure 2 and Figure 3, the two models are different regarding design of charging infrastructure, where the construction of charging infrastructure is a separate process before the procurement of bus traffic in the first model, but not in the second model. The first step about design of the bus ecosystem is, however, identical in both models. During this step, it will become clear about involved stakeholders' experience and knowledge about electric bus systems, and also if it is preferable to use opportunity or depot charging. The stakeholders (primarily the regional PTA) can then move on to the next step. The charging infrastructure design step should, as in model 1, be led by the regional PTA or charging operator, or alternatively, as in model 2 , be led by the bus operator. 


\section{Concluding Discussion}

\section{Main Findings}

This study aimed to use stakeholder collaboration to investigate how to include electric bus systems in the current procurement process for public bus transport. Two models were developed that included stakeholders/roles and their respective leaderships/responsibilities, partners to establish contracts with, and stakeholder collaboration steps. The first model fits opportunity charged buses and/or stakeholders with a low level of experience of electric bus systems, while the second fits depot-charged buses and/or stakeholders with a high level of experience of electric bus systems. The first steps about bus ecosystem and charging infrastructure design that were common for both models should be used during "stakeholder consultation" in the current procurement process. Unlike the second model, the first model suggests that construction of charging infrastructure should be started after the decision whether procurement should be done, and chargers must be operational before commissioning the bus traffic.

\section{Comparison with Other Studies}

The most comparable study was a local project in Gothenburg called Energy Transfer Solutions for Electrified Bus Systems-EAEB (Östling 2018). This project aimed to support a dialogue on procurement of electrified bus systems. It conducted a role-playing workshop during 2017 that involved local electric bus traffic stakeholders. It resulted in the identification of three different scenarios depending of the level of knowledge and ambitions among stakeholders. It also found that the actors want flexibility with limited, but not zero, interventions by the regional PTA. In line with this study, the results from the EAEB project show not only that it is important to agree among actors at an early stage in the procurement process about the bus ecosystem and charging infrastructure design, but also that the electric bus systems knowledge among stakeholders defines how the procurement process should be executed.

\section{Validity}

This study assumes that electric buses and charging infrastructure will be depreciated within ten years. The chargers might have some value after ten years, but that is hard to estimate due to lack of data, and it will probably be low enough to not affect the proposed models in this study. It will be far more important that the procurement process leads to an effective bus ecosystem than to extend the life of the chargers after the end of the first bus traffic contract period. Moreover, it is likely that PTAs, to ensure the quality of the electric bus system, would prefer to include new chargers in the procurement rather than old ones from the previous procurement period.

Stakeholders from two bus manufacturers, four bus operators, three electricity grid owners (and dealers), three charging operators, four municipalities, four PTAs, and one national bus traffic association were represented in the study, but the results could have been further anchored if even more actors would have been included. It is, though, important that participation in research collaboration projects builds on interest from participating actors. More than thirty actors were invited to join this study, but some declined as they were not able to prioritize their participation, so the authors of this study believe that it was not possible to get more actors into the study when it was commissioned. 


\section{Societal Impact and Further Studies}

The results of this study give guidelines for how to enhance the introduction of electric buses in the current procurement process, which can support the transition towards sustainability and interim goals like fossil-fuel-independent transport and greenhouse-gas-neutral society. The authors believe that the two models found in the study should be further developed when tested in upcoming procurements of public bus transport that includes electric bus traffic to some extent (e.g., one or several routes in a bus system for a city or a municipality).

\section{Recommendations}

The authors of this report recommend that early in an investigation of introduction of electric buses, the PTAs should analyze the need for a modification of their normal procurement process and start early with the first step of bus ecosystem design. There can be a delay of months or even years between design and construction of charging infrastructure due to processing of building permits and/or redesign of the electricity grid. Added to that, the authors also recommend, if possible, locating the bus depots fairly close to the bus lines that are about to be electrified to increase efficiency of the whole bus system.

\section{Acknowledgement}

Partners in this study from Affärsverken AB (Karlskrona), Göteborg Energi, Electrodriving, Region Jönköpings län, Nobina, Karlstadsbuss, Karlskrona Kommun, Orust kommun, Skånetrafiken, Stockholms lokaltrafik, Svealandstrafiken AB, Svensk Kollektivtrafik, Vattenfall $\mathrm{AB}$, and Volvo Buses have been very helpful regarding co-creation of the results in this study. Former BTH PhD student Lisiana Nurhadi provided great support at the first workshop. Supervisor and project leader Henrik Ny provided great support throughout the creation and execution of the study and gave great feedback on this article.

\section{REFERENCES}

Aldenius, Malin, and Jamil Khan. 2017. "Strategic Use of Green Public Procurement in the Bus Sector: Challenges and Opportunities." Journal of Cleaner Production 164: 250-57. https://doi.org/10.1016/j.jclepro.2017.06.196.

Borén, Sven. 2015. "Green Charge - Demotest I Fält Med Elbuss" [Green Charge - In Real Life Testing of Electric Buses]. Edited by Henrik Ny, Lisiana Nurhadi, Jonas Lööf, and Stefan Nilsson. Karlskrona: Blekinge Institute of Technology. http://greencharge.se/forskning/rapport-falttestet-med-elbuss/.

Borén, Sven, and Henrik Ny. 2016a. "Decision Support for Procurement of Electric Buses in Public Transport." SustainTrans. Karlskrona. https://a.bth.se/sustaintrans/portfolioitems/decision-support-for-procurement-of-electric-buses-in-publictransport/?portfolioCats $=19$.

2016b. "A Strategic Sustainability Analysis of Electric Vehicles in EU Today and Towards 2050." International Journal of Environmental, Chemical, Ecological, Geological, and Geophysical Engineering 10 (3): 207-15. http://waset.org/publications/10003726/a-strategic-sustainability-analysis-of-electricvehicles-in-eu-today-and-towards-2050.

Borén, Sven, Lisiana Nurhadi, and Henrik Ny. 2016. "Preference of Electric Buses in Public Transport; Conclusions From Real Life Testing in Eight Swedish Municipalities." International Journal of Environmental, Chemical, Ecological, Geological, and 
Geophysical Engineering 10 (3): 255-64. http://waset.org/publications/10003929 /preferences-of-electric-buses-in-public-transport-conclusions-from-real-life-testing-ineight-swedish-municipalities.

Broman, Göran Ingvar, and Karl-Henrik Robèrt. 2017. "A Framework for Strategic Sustainable Development." Journal of Cleaner Production 140 (Part 1): 17-31. https://doi.org/10.1016/j.jclepro.2015.10.121.

Cazzola, Pierpaolo. 2018. "Global EV Outlook 2018." International Energy Agency. https://webstore.iea.org/download/direct/1045?fileName=Global_EV_Outlook_2018.pdf.

Ecotraffic. 2015. "Kunskapssammanställning - EURO VI Stadsbussar" [Kñowledge Summary of Euro VI City Buses]. Report 157078. Trafikverket. http://www.ecotraffic.se/media /10543/rapport_7078_-_kunskapspm-euro_vi-stadsbussar_final_.pdf.

Edwards, Robert, Jean-Francois Larive, David Rickeard, and Werner Weindorf. 2014. "WELLto-TANK Report Version 4.a JEC WELL-to-WHEELS ANALYSIS .” EUR 26237 EN. 4 ed. Luxembourg: Frontiers. https://doi.org/10.2790/95629.

Ekström, Adam, and Robert Regula. 2016. "Identifying Barriers in a Technological Shift: the Introduction of Battery- Electric Buses in Swedish Public Transport." Master's thesis, KTH Royal Institute of Technology. https://www.divaportal.org/smash/get/diva2:1060614/FULLTEXT01.pdf.

Faria, Ricardo, Pedro Moura, Joaquim Delgado, and Anibal T de Almeida. 2012. "A Sustainability Assessment of Electric Vehicles as a Personal Mobility System." Energy Conversion and Management $61 \quad$ (0): 19-30. https://doi.org/10.1016/j.enconman.2012.02.023.

Hallberg, Lisa, Tomas Rydberg, Lisa Bolin, Lisbeth Dahllöf, Helen Mikaelsson, Eva Iverfeldt, and Johan Tivander. 2013. "Well-to-Wheel Lci Data for Fossil and Renewable Fuels on the Swedish Market." 2013:29. f3 The Swedish Knowledge Centre for Renewable Transportation Fuels. https://f3centre.se/app/uploads/f3-Report-2013-29_LCIDatabase_141215.pdf

Hawkins, Troy R, Hawkins, Troy R, Bhawna Singh, Bhawna Singh, Guillaume Majeau-Bettez, Guillaume Majeau-Bettez, Anders Hammer Strømman, and Anders Hammer Strømman. 2012. "Comparative Environmental Life Cycle Assessment of Conventional and Electric Vehicles." Journal of Industrial Ecology 17 (1): 53-64. https://doi.org/10.1111/j.1530-9290.2012.00532.x.

Johansson, Thomas B, Per Kågesson, Håkan Johansson, Lina Jonsson, Jonas Westin, Hillevi Hejenstedt, Olle Hådell, Kristina Holmgren, and Per Wollin. 2013. "Fossilfrihet På Väg” [Towards Fossil Free Transport]. SOU 2013:84. Stockholm: Fritzes Offentliga Publikationer. https:/www.regeringen.se/49bbab/contentassets/ 7bb237f0adf546daa36aaf044922f473/fossilfrihet-pa-vag-sou-201384-del-12.

Nordelöf, Anders, Maarten Messagie, Anne-Marie Tillman, Maria Ljunggren Söderman, and Joeri Van Mierlo. 2014. "Environmental Impacts of Hybrid, Plug-in Hybrid, and Battery Electric Vehicles-What Can We Learn From Life Cycle Assessment?" The International Journal of Life Cycle Assessment 19 (11): 1866-90. https://doi.org/10.1007/s11367-014-0788-0.

Nordelöf, Anders, Mia Romare, and Johan Tivander. 2017. "Miljöpåverkan Från Elektriska Stadsbussar" [Environmental Effects from Electric City Buses]. 2017:9. Gothenburg: Chalmers Tekniska Högskola. https://research.chalmers.se/publication/254814 /file/254814_Fulltext.pdf.

Nurhadi, Lisiana, Sven Borén, and Henrik Ny. 2014. "Advancing From Efficiency to Sustainability in Swedish Medium-Sized Cities: an Approach for Recommending Powertrains and Energy Carriers for Public Bus Transport Systems." Procedia - Social and Behavioral Sciences 111:586-95. https://doi.org/10.1016/j.sbspro.2014.01.092.

Östling, Johan. 2018. "Energy Transfer Solutions for Electrified Bus Systems." 2015-007386. Eskilstuna: The Swedish Energy Agency. http://www.energimyndigheten.se/forskning- 
och-innovation/projektdatabas/sokresultat/GetDocument/?id=74c54a94-0e7a-47499f66-4b3f8faeb5a5\&documentName=41407-1\%20Slutrapport\%20EAEB\%2018-0328\%20Energimyndigheten.pdf.pdf.

Paulsson, Alexander, Karolina Isaksson, Robert Hrelja, Tom Rye, Christina Lindkvist Scholten, and Claus Hedegaard Sörensen. 2018. "Samverkan I Kollektivtrafiken" [Collaboration in Public transport]. K2 OUTREACH 2018:1. Lund: K2 - Nationellt Kunskapscentrum för Kollektivtrafik. http://www.k2centrum.se/sites/default/files/fields /field_uppladdad_rapport/samverkan_i_kollektivtrafiken_k2_outreach_2018_1.pdf.

Svensk Kollektivtrafik ${ }^{-}$AB, Nobina, Branschföreningen Tågoperatörerna, Svenska Taxiförbundet, BR, Stockholms Lokaltrafik, Östgötatrafiken, Kollektivtrafikmyndigheten Västernorrlands län, Västra Götalandsregionen, Skånetrafiken. 2013. "Avtalsprocess För Fördubblad Kollektivtrafik" [Contracting Process for Doubling of Public Transport]. Svensk Kollektivtrafik AB. https://www.svenskkollektivtrafik.se/globalassets/partnersamverkan/dokument/mallavta 1-och-kravbilagor/handlingar-modellavtal-2013/3_avtalsprocessen-augusti-2013.pdf.

UITP. 2017. "ZeEUS eBus Report \#2: An Updated Overview of Electric Buses in Europe." UITP. http://zeeus.eu/uploads/publications/documents/zeeus-report2017-2018-final.pdf.

United Nations. 2015. "Adoption of the Paris Agreement." United Nations. https://unfccc.int/resource/docs/2015/cop21/eng/109r01.pdf.

Wei, Ran, Xiaoyue Liu, Yi Ou, and S Kiavash Fayyaz. 2018. "Optimizing the Spatio-Temporal Deployment of Battery Electric Bus System." Journal of Transport Geography 68 (April): 160-68. https://doi.org/10.1016/j.jtrangeo.2018.03.013.

Xylia, Maria, Sylvain Leduc, Piera Patrizio, Florian Kraxner, and Semida Silveira. 2017. "Locating Charging Infrastructure for Electric Buses in Stockholm." Transportation Research Part C: Emerging Technologies 78 (May): 183-200. https://doi.org/10.1016/j.trc.2017.03.005.

\section{ABOUT THE AUTHORS}

Sven Borén, PhD: Strategic Sustainable Development, Blekinge Institute of Technology, Karlskrona, Sweden

Anders Grauers: Associate Professor, Electrical Engineering, Chalmers University of Technology, Gothenburg, Sweden 
The International Journal of Sustainability Policy

and Practice is one of three thematically focused

journals in the family of journals that support the On

Sustainability Research Network -its journals, book

imprint, conference, and online community. The

journal addresses sustainability agendas and the practices flowing from these in government, corporate, and community sectors.

In addition to traditional scholarly papers, this journal invites presentations of sustainability practicesincluding documentation of case studies and exegeses analyzing the effects of these practices.

The International Journal of Sustainability Policy and Practice is a peer-reviewed, scholarly journal. 